Vol. 1 No. 02 Hal. $44-52$

September 2018

\title{
Hubungan Reklame Rokok Dengan Perilaku Merokok Pelajar SMA Negeri 4 di Kota Pematangsiantar Tahun 2017
}

\author{
Maswan Daulay $^{(1)}$, Juliandi Harahap ${ }^{(2)}$, Barsyariah Lubis ${ }^{(3)}$, Saiful Batubara ${ }^{(4)}$ \\ ${ }^{(1)(2)(3)}$ Dosen STIKes DHDT PNS DPK Kopertis Program Studi Magister Kesehatan Masyarakat \\ ${ }^{(4)}$ Dosen PNS DPK Kopertis Universitas Islam Sumatera Utara \\ maswandaulay@gmail,com ${ }^{(1)}$, harahapjuliandi@gmail.com ${ }^{(2)}$, basyariahlbs@gmail.com ${ }^{(3)}$, \\ saifulbatubara24@gmail.com ${ }^{(4)}$
}

\begin{abstract}
The setting up of cigarette advertisements to introduce and attract public attention to cigarettes. But not according to government regulation no. 109 of 2012, indirectly have a negative impact on smoking behavior for adolescents. The type of research is observational with cross sectional design and conducted on May in 2017. Samples of the research were 418 people (students of class X and XI) in SMA Negeri 4 Pematangsiantar City. Data collection used questionnaires that distributed to respondents. Data analysis was performed by chi-square test at $95 \%$ significance level.The result of the research show that the dominant student exposed to cigarette advertisement majority who have bad knowledge is 111 person $(54,4 \%)$, student not dominant exposed to cigarette advertisement majority who have good attitude is 143 person $(66,8 \%)$, student not dominantly exposed to cigarette advertisement of the majority who is not smoking is 117 people $(54,7 \%)$ and students who are not exposed to cigarette advertisement who are the majority of good behavior is 125 people $(58,4 \%)$. Then there is relationship between cigarette billboards with knowledge with the value $\mathrm{p}=0.001$ and there is a cigarette advertisement relationship with the attitude with the value $p=0.003$. However, the practice variable have no relationship to the value of $p=0,113$, so there is relationship of cigarette advertisement with smoking behavior on student with nilap $\mathrm{p}=0,015$, it means that cigarette advertisement can influence smoking behavior in adolescents either have positive or negative impact. The more commonly seen cigarette advertisements can affect the behavior of smokers, however, in some circumstances may also affect students not to smoke. It is suggested to Pematangsiantar City Government through Education and Health Office to make local policy that related to cigarette advertisement according to government regulation
\end{abstract}

\section{PENDAHULUAN}

Merokok merupakan masalah yang belum bisa terselesaikan hingga saat ini. Merokok sudah melanda berbagai kalangan, baik anak-anak sampai orang tua, laki-laki maupun perempuan, terlebih pada pelajar-siswi SMU. Dari data World Health Organization (WHO) pada tahun 2014 menyebutkan bahwa merokok dapat membunuh hingga setengah dari pengkonsumsi rokok. Berdasarkan hasil Riskesdas tahun 2013, rata-rata perilaku merokok di Indonesia saat ini sebesar 29,3\%. Proporsi perokok terbanyak terdapat di Kepulauan Riau dengan jumlah perokok setiap hari 27,2\%. Proporsi merokok penduduk umur 15 tahun ke atas cenderung meningkat, dari tahun 2007 sebesar 34,2\% meningkat menjadi 36,3\% di tahun 2013 sedangkan untuk Jawa Tengah proporsi perokok usia di atas 10 tahun yang merokok setiap hari sebesar 22,9\% dan perokok kadang-kadang sebesar $5,3 \%$ dengan jumlah batang yang dihisap dalam sehari pada saat ini sebesar $10,7 \%$ (Riskesdas, 2013). Munculnya budaya merokok dikalangan remaja diakibatkan oleh 
pergaulan dan terutama gencarnya iklan rokok yang mendorong remaja untuk merokok. Menurut Nurmayunita, dkk (2015) dalam penelitiannya yang berjudul hubungan antara pengetahuan, paparan media iklan dan persepsi dengan tingkat perilaku merokok pelajar SMK Kasatrian Solo Kartasura Sukoharjo dijelaskan bahwa pelajar yang jarang melihat iklan rokok justru lebih banyak memiliki tingkat perilaku merokok sedang sebesar $71,4 \%$ dibandingkan responden yang sering melihat iklan rokok malah lebih banyak pada tingkat perilaku merokok ringan sebesar 61,8\%. Pada tahun 2014 Pemerintah Kota (Pemko) dan DPRD Medan sepakat dan resmi memberlakukan Peraturan Daerah (Perda) Kota Medan Nomor 3 Tahun 2014 tentang Kawasan Tanpa Rokok. Namun kenyataannya pengawasan dan pemberlakuan saksi di dalam perda ini masih sangat minim. Di Kota Pematansiantar tidak ditemukan data mengenai jumlah pasti perokok terutama dikalangan remaja, bahkan peraturan daerah terkait dengan pemasangan reklame rokok tidak tertulis karena reklame rokok yang dipajang di beberapa tempat khususnya di jalan utama atau protokol yang ada di Kota Pematangsiatar adalah salah satu pemasukan daerah, semakin banyak reklame rokok yang dipajang maka semakin banyak pemasukan daerah tersebut. SMA Negeri 4 Pematangsiantar adalah salah satu SMA favorit di Kota Pematangsiantar sehingga diasumsikan bahwa pengetahuannya lebih tinggi dari SMA lainnya dimana diasumsikan mereka akan lebih mengetahui tentang bahaya rokok bagi kesehatan dan menghindarinya sehingga peneliti berkeinginan meneliti di SMA tersebut. Berdasarkan latar belakang diatas maka peneliti tertarik untuk melakukan penelitian tentang hubungan reklame rokok dengan perilaku merokok pelajar SMA Negeri 4 di Kota Pematangsiantar.

\section{METODE PENELITIAN}

Penelitian ini merupakan penelitian observasional dengan jenis cross-sactional dan telah dilaksanakan di SMA Negeri 4 di Kota Pematangsiantar mulai bulan Februari-April 2017. Sampel dalam penelitian ini adalah seluruh pelajar Kelas X dan XI yang ada di SMA Negeri 4 Kota Pematangsiantar sebanyak 418 orang.

\section{HASIL PENELITIAN}

\section{a. Reklame Rokok}

Reklame rokok terkait dengan keterpaparan responden terhadap reklame rokok. Distribusi responden berkaitan dengan keterpaparan responden terhadap reklame rokok dapat dilihat pada tabel berikut:

Tabel 4.1. Distribusi Keterpaparan Reklame Rokok pada Pelajar di SMA Negeri 4 Kota Pematangsiantar

\begin{tabular}{|c|c|c|}
\hline Keterpaparan Reklame Rokok & n & \% \\
\hline Dominan & 204 & 48,80 \\
\hline Tidak Dominan & 214 & 51,20 \\
\hline Total & 418 & 100,00 \\
\hline
\end{tabular}

Berdasarkan Tabel 4.1. dapat dilihat bahwa keterpaparan pelajar terhadap reklame rokok mayoritas tidak dominan yaitu sebanyak 214 orang $(51,20 \%)$.

\section{b. Pengetahuan}

Pengetahuan responden berkaitan dengan segala sesuatu yang diketahui oleh responden tentang rokok dan reklame rokok. Distribusi responden berdasarkan pengetahuan dapat dilihat pada tabel berikut: 
Tabel 4.2. Distribusi Pengetahuan tentang Rokok pada Pelajar di SMA Negeri 4 Kota Pematangsiantar

\begin{tabular}{|c|c|c|}
\hline Pengetahuan & n & \% \\
\hline Baik & 225 & 53,80 \\
\hline Tidak Baik & 193 & 46,20 \\
\hline Total & 418 & 100,00 \\
\hline
\end{tabular}

Berdasarkan Tabel 4.2. dapat dilihat bahwa pengetahuan tentang rokok pada pelajar mayoritas baik yaitu sebanyak 225 orang $(53,80 \%)$.

c. Sikap

Sikap responden berkaitan dengan pendapat responden tentang rokok dan reklame rokok. Distribusi responden berdasarkan sikap dapat dilihat pada tabel berikut:

Tabel 4.3. Distribusi Sikap tentang Rokok pada Pelajar di SMA Negeri 4 Kota Pematangsiantar

\begin{tabular}{|c|c|c|}
\hline Sikap & n & \% \\
\hline Baik & 249 & 59,60 \\
\hline Tidak Baik & 169 & 40,40 \\
\hline Total & 418 & 100,00 \\
\hline
\end{tabular}

Berdasarkan Tabel 4.3. dapat dilihat bahwa sikap tentang rokok pada pelajar mayoritas baik yaitu sebanyak 249 orang $(59,60 \%)$.

\section{d. Tindakan}

Tindakan responden berkaitan dengan aksi responden terhadap kebiasaan merokok. Distribusi responden berdasarkan tindakan dapat dilihat pada tabel berikut:

Tabel 4.4. Distribusi Tindakan merokok pada Pelajar di SMA Negeri 4 Kota Pematangsiantar

Berdasarkan

\begin{tabular}{|c|c|c|}
\hline Tindakan & n & \% \\
\hline Tidak Merokok & 229 & 54,8 \\
\hline Perokok Ringan & 47 & 11,2 \\
\hline Perokok Sedang & 81 & 19,4 \\
\hline Perokok Berat & 61 & 14,6 \\
\hline Total & 418 & 100,0 \\
\hline
\end{tabular}

dilihat bahwa sebanyak 47 orang $(11,2 \%)$ perokok ringan, 81 orang $(19,4 \%)$ perokok sedang dan 61 orang $(14,6 \%)$ perokok berat dan yang tidak merokok sebanyak 229 orang $(54,8 \%)$.

\section{e. Perilaku}

Perilaku adalah berkaitan dengan pengetahuan, sikap dan tindakan pelajar tentang rokok. Distribusi responden berdasarkan perilaku dapat dilihat pada tabel berikut:

Tabel 4.5. Distribusi Perilaku merokok pada Pelajar di SMA Negeri 4 Kota Pematangsiantar

\begin{tabular}{|c|c|c|}
\hline Perilaku & n & \% \\
\hline Baik & 219 & 52,4 \\
\hline Tidak Baik & 199 & 47,6 \\
\hline Total & 418 & 100,0 \\
\hline
\end{tabular}


Maswan D, Juliandi H, Basyariah L, Saiful B : Hubungan Reklame Rokok Dengan Perilaku Merokok Pelajar SMA Negeri 4 di Kota Pematangsiantar Tahun 2017

Berdasarkan Tabel 4.5. dapat dilihat bahwa perilaku merokok pada pelajar mayoritas baik yaitu sebanyak 219 orang $(52,4 \%)$.

\section{f. Hubungan Reklame Rokok dengan Pengetahuan}

Keterpaparan responden terhadap reklame rokok dapat mempengaruhi pengetahuan pelajar tentang rokok. Distribusi responden berkaitan dengan hubungan reklame rokok dengan pengetahuan dapat dilihat pada tabel berikut:

Tabel 4.6. Hubungan Keterpaparan Reklame Rokok dengan Pengetahuan tentang Rokok pada Pelajar di SMA Negeri 4 Kota Pematangsiantar

\begin{tabular}{|c|c|c|c|c|c|c|c|}
\hline \multirow[t]{3}{*}{ Keterpaparan Reklame Rokok } & \multicolumn{4}{|c|}{ Pengetahuan } & \multirow{2}{*}{\multicolumn{2}{|c|}{ Jumlah }} & \multirow[t]{3}{*}{ p value } \\
\hline & \multicolumn{2}{|c|}{ Baik } & \multicolumn{2}{|c|}{ Tidak Baik } & & & \\
\hline & $\mathbf{n}$ & $\%$ & $\mathbf{n}$ & $\%$ & $\mathbf{n}$ & $\%$ & \\
\hline Dominan & 93 & 45,6 & 111 & 54,4 & 204 & 100,0 & \\
\hline Tidak Dominan & 132 & 61,7 & 82 & 38,3 & 214 & 100,0 & \\
\hline
\end{tabular}

Berdasarkan hasil analisis didapat bahwa nilai $\mathrm{p}=0,001<$ alpha $=0,05$, ini berarti Ha diterima yang artinya bahwa ada hubungan keterpaparan reklame rokok dengan pengetahuan tentang rokok pada pelajar di SMA Negeri 4 Kota Pematangsiantar.

\section{g. Hubungan Reklame Rokok dengan Sikap}

Keterpaparan responden terhadap reklame rokok dapat mempengaruhi sikap pelajar tentang rokok. Distribusi responden berkaitan dengan hubungan reklame rokok dengan sikap dapat dilihat pada tabel berikut:

Tabel 4.7. Hubungan Keterpaparan Reklame Rokok dengan Sikap tentang Rokok pada Pelajar di SMA Negeri 4 Kota Pematangsiantar

\begin{tabular}{|l|c|c|c|c|c|c|c|}
\hline \multirow{2}{*}{ Keterpaparan Reklame Rokok } & \multicolumn{4}{|c|}{ Sikap } & \multicolumn{2}{c|}{ Jumlah } & \multirow{2}{*}{ v value } \\
\cline { 2 - 7 } & \multicolumn{3}{|c|}{ Baik } & \multicolumn{2}{|c|}{ Tidak Baik } & \\
\cline { 2 - 7 } & $\mathbf{n}$ & $\%$ & $\mathbf{n}$ & $\%$ & $\mathbf{n}$ & $\%$ & \\
\hline Dominan & 106 & 52,0 & 98 & 48,0 & 204 & 100,0 & \multirow{2}{*}{0,003} \\
\hline Tidak Dominan & 143 & 66,8 & 71 & 33,2 & 214 & 100,0 & \\
\hline
\end{tabular}

Berdasarkan hasil penelitian didapat nilai $\mathrm{p}=0,003<$ alpha $=0,05$, ini berarti $\mathrm{Ha}$ diterima yang artinya bahwa ada hubungan keterpaparan reklame rokok dengan sikap tentang rokok pada pelajar di SMA Negeri 4 Kota Pematangsiantar.

h. Hubungan Reklame Rokok dengan Tindakan

Keterpaparan responden terhadap reklame rokok dapat mempengaruhi tindakan merokok pada pelajar. Distribusi responden berkaitan dengan hubungan reklame rokok dengan tindakan merokok dapat dilihat pada tabel berikut:

Tabel 4.8. Hubungan Keterpaparan Reklame Rokok dengan Tindakan Merokok pada Pelajar di SMA Negeri 4 Kota Pematangsiantar

\begin{tabular}{|c|c|c|c|c|c|c|c|c|c|c|c|}
\hline \multirow{3}{*}{$\begin{array}{c}\text { Keterpaparan } \\
\text { Reklame Rokok }\end{array}$} & \multicolumn{9}{|c|}{ Tindakan } & \multirow[t]{2}{*}{ Jumlah } & \multirow[t]{3}{*}{$\overline{p \text { value }}$} \\
\hline & \multicolumn{2}{|c|}{ Tidak Merokok } & \multicolumn{2}{|c|}{ Perokok ringan } & \multicolumn{3}{|c|}{ Perokok Sedang } & \multicolumn{2}{|c|}{ Perokok Berat } & & \\
\hline & $\mathbf{n}$ & $\%$ & $\mathbf{n}$ & $\%$ & $\mathbf{n}$ & $\%$ & $\mathbf{n}$ & $\%$ & $\mathbf{n}$ & $\%$ & \\
\hline Dominan & 112 & 54,9 & 27 & 13,2 & 43 & 21,1 & 22 & 10,8 & 204 & 100,0 & 0,113 \\
\hline Tidak Dominan & 117 & 54,7 & 20 & 9,3 & 38 & 17,8 & 39 & 18,2 & 214 & 100,0 & \\
\hline
\end{tabular}

Berdasarkan hasil penelitian juga didapat bahwa nilai $\mathrm{p}=0,113>$ alpha $=0,05$, ini berarti Ha ditolak yang artinya bahwa tidak ada hubungan keterpaparan reklame rokok dengan tindakan merokok pada pelajar di SMA Negeri 4 Kota Pematangsiantar.

\section{i. Hubungan Reklame Rokok dengan Perilaku}

Keterpaparan responden terhadap reklame rokok dapat mempengaruhi perilaku pelajar tentang rokok. Distribusi responden berkaitan dengan hubungan reklame rokok dengan perilaku dapat dilihat pada tabel berikut: 
Maswan D, Juliandi H, Basyariah L, Saiful B : Hubungan Reklame Rokok Dengan Perilaku Merokok Pelajar SMA Negeri 4 di Kota Pematangsiantar Tahun 2017

Tabel 4.9. Hubungan Keterpaparan Reklame Rokok dengan Perilaku Merokok pada Pelajar di SMA Negeri 4 Kota Pematangsiantar

\begin{tabular}{|c|c|c|c|c|c|c|c|}
\hline \multirow[t]{3}{*}{ Keterpaparan Reklame Rokok } & \multicolumn{4}{|c|}{ Perilaku } & \multicolumn{2}{|c|}{ Jumlah } & \multirow[t]{3}{*}{ p value } \\
\hline & \multicolumn{2}{|c|}{ Baik } & \multicolumn{2}{|c|}{ Tidak Baik } & & & \\
\hline & $\mathbf{n}$ & $\%$ & $\mathbf{n}$ & $\%$ & $\mathbf{n}$ & $\%$ & \\
\hline Dominan & 94 & 46,1 & 110 & 53,9 & 204 & 100,0 & \\
\hline Tidak Dominan & 125 & 58,4 & 89 & 41,6 & 214 & 100,0 & \\
\hline
\end{tabular}

Berdasarkan hasil penelitian didapat bahwa nilai $\mathrm{p}=0,015<$ alpha $=0,05$, ini berarti Ha diterima yang artinya bahwa ada hubungan keterpaparan reklame rokok dengan perilaku merokok pada pelajar di SMA Negeri 4 Kota Pematangsiantar.

\section{PEMBAHASAN}

\section{a. Reklame Rokok}

Dari hasil penelitian didapat bahwa keterpaparan pelajar terhadap reklame rokok mayoritas tidak dominan yaitu sebanyak 214 orang $(51,20 \%)$ dimana pelajar tersebut melihat reklame rokok < dari 24 kali dalam 1 bulan, namun jumlah ini tidak jauh berbeda dengan pelajar yang dominan melihat reklame rokok yaitu sebanyak 204 orang $(48,8 \%)$.

Menurut Juniarti dalam Tarwoto, dkk (2010), melihat iklan di media massa dan media elektronik yang menampilkan gambaran perokok adalah lambang kejantanan atau glamour, membuat remaja seringkali terpicu untuk mengikuti perilaku seperti yang ada di iklan tersebut.

\section{b. Pengetahuan}

Dari hasil penelitian didapat bahwa pengetahuan tentang rokok pada pelajar mayoritas baik yaitu sebanyak 225 orang $(53,80 \%)$ dengan ini maka pelajar sudah mengetahui dampak negatif dari merokok tersebut. Dengan memiliki pengetahuan yang baik harapannya pelajar-pelajar tersebut menghindarkan diri dari tindakan merokok.

Dengan melihat reklame rokok pelajar dapat menambah pengetahuan tentang rokok, namun terkadang tidak semua pelajar dapat menyikapi reklame rokok tersebut dengan benar, reklame rokok yang sering dikemas dengan sangat bagus yang tersekan mewah dan keren sehingga mengenyampingkan pesan yang harusnya disampaikan.

Menurut Khairul (2014) salah satu faktor-faktor yang mempengaruhi perilaku merokok pada remaja adalah pengetahuan yang kurang terhadap bahaya merokok, para remaja mengganggap kebiasaan merokok adalah suatu hal yang biasa dilakukan oleh remaja masa kini.

\section{c. Sikap}

Dari hasil penelitian didapat bahwa sikap tentang rokok pada pelajar mayoritas baik yaitu sebanyak 249 orang $(59,60 \%)$. Seorang pelajar tidak seharusnya merokok, selain dapat mengganggu kesehatan juga dapat membuat pelajar tersebut sulit untuk berkonsentrasi terhadap pelajarannya sehingga dapat mempengaruhi nilai di sekolah.

Namun bagi beberapa pelajar menjadikan rokok sebagai rutinitas sehari-hari sehingga sulit untuk meninggalkannya walaupun pelajar tersebut mengerti bahwa hal tersebut harus dihindari karena memiliki dampak yang tidak baik terhadap dirinya sendiri sehingga sikap yang baik tentang rokok sering sekali tidak sejalan dengan kebiasaan merokok pada pelajar tersebut.

Pada penelitian Siti Nurfadilah (2015) mayoritas responden memiliki sikap yang baik tentang rokok yaitu sebanyak 102 orang $(67,5 \%)$, seseorang yang memiliki sikap yang baik tentang rokok otomatis tidak akan merokok, mereka akan tetap mencoba merokok meskipun mereka mengetahui bahwa merokok tidak baik untuk kesehatan, hal ini didapat karena 
Maswan D, Juliandi H, Basyariah L, Saiful B : Hubungan Reklame Rokok Dengan Perilaku Merokok Pelajar SMA Negeri 4 di Kota Pematangsiantar Tahun 2017

responden sudah terlanjur memiliki kebiasaan untuk merokok sehingga sulit untuk berhenti merokok.

\section{d. Tindakan}

Dari hasil penelitian didapat bahwa tindakan merokok pada pelajar mayoritas tidak merokok yaitu sebanyak 229 orang $(54,8 \%)$ namun terdapat 189 orang pelajar yang merokok dengan rincian perokok berat sebanyak 61 orang $(14,6 \%)$, perokok sedang 81 orang $(19,4 \%)$ dan perokok ringan sebanyak 47 orang $(11,2 \%)$.

Menurut Aula (2010) bahwa reklame merokok yang selalu memperlihatkan seseorang yang sedang merokok, biasanya mereka memperhatikan tindakan orang lain dan kadang kala mencoba untuk meniru perlakuannya. Hal ini sebagai suatu proses yang terjadi pada remaja untuk mencari jati diri dan belajar menjalani hidup. Namun, sangat disayangkan karena tidak hanya kebiasaan - kebiasaan yang baik saja yang ditiru, melainkan juga kebiasaan - kebiasaan buruk, termasuk kebiasaan merokok.

\section{e. Perilaku}

Dari hasil penelitian didapat bahwa perilaku merokok pada pelajar mayoritas baik yaitu sebanyak 219 orang $(52,4 \%)$ namun masih terdapat pelajar yang memiliki perilaku merokok yang tidak baik yaitu sebanyak 199 orang $(47,6 \%)$.

Hal ini cukup menghawatirkan, dengan jumlah pelajar yang merokok dan berperilaku tidak baik yang cukup banyak ditakutkan akan memberi dampak yang tidak baik kepada teman-temannya sehingga tidak menutup kemungkinan jumlah ini akan terus bertambah jika tidak segera ditangani dengan baik.

Hal ini sesuai dengan pernyataan Kholid (2011) bahwa remaja yang sudah kecanduan nikotin akan meningkatkan konsumsi rokoknya. Rasa sensitif terhadap nikotin tersebut juga akan mempengaruhi fungsi otak dan disetiap aktifitasnya selalu menyempatkan untuk merokok apabila tidak merokok siswa akan cenderung lemas dan tidak bersemangat.

\section{f. Hubungan Reklame Rokok dengan Pengetahuan}

Dari hasil penelitian didapat bahwa bahwa $\mathrm{p}=0,001<$ alpha $=0,05$, ini berarti Ha diterima yang artinya bahwa ada hubungan keterpaparan reklame rokok dengan pengetahuan tentang rokok pada pelajar di SMA Negeri 4 Kota Pematangsiantar.

Hasil penelitian ini sejalan dengan penelitian Hasanah dan Sulastri (2012) yang menunjukkan ada hubungan dukungan iklan rokok dengan perilaku merokok remaja dimana semakin sering melihat iklan rokok maka semakin tertarik untuk mencoba menghisap rokok.

Selain itu hasil penelitian Dewanta (2013), yang menunjukkan bahwa semakin tinggi paparan iklan rokok maka semakin tidak baik pengetahuannya dan mendorong mahasiswi perokok untuk terus merokok

\section{g. Hubungan Reklame Rokok dengan Sikap}

Dari hasil penelitian didapat bahwa $\mathrm{p}=0,003<$ alpha $=0,05$, ini berarti Ha diterima yang artinya bahwa ada hubungan keterpaparan reklame rokok dengan sikap tentang rokok pada pelajar di SMA Negeri 4 Kota Pematangsiantar.

Hal ini sesuai dengan penelitian Baskoro (2005) yang menyatakan bahwa terdapat hubungan positif antara sikap tentang reklame rokok dengan perilaku merokok, dan dapat meningkatkan kecenderungan untuk berhenti merokok. Pada penelitian ini didapat bahwa responden mengaku reklame rokok memiliki pengaruh terhadap perilaku merokok.

\section{h. Hubungan Reklame Rokok dengan Tindakan}

Dari hasil penelitian didapat bahwa $\mathrm{p}=0,113>$ alpha $=0,05$, ini berarti Ha ditolak yang artinya bahwa tidak ada hubungan keterpaparan reklame rokok dengan tindakan merokok pada pelajar di SMA Negeri 4 Kota Pematangsiantar. Hal ini dikarenakan 
Maswan D, Juliandi H, Basyariah L, Saiful B : Hubungan Reklame Rokok Dengan Perilaku Merokok Pelajar SMA Negeri 4 di Kota Pematangsiantar Tahun 2017

sebanyak 229 orang responden tidak merokok yang terdiri dari 33 orang laki-laki dan 196 orang perempuan.

Menurut Kuswandi (2011) adanya pelajar yang merokok tersebut dikarenakan remaja merupakan kelompok tertinggi yang rentan terhadap pengaruh iklan, baik di media massa (cetak dan elektronik) maupun papan iklan dipinggir jalan. Intensitas melihat peringatan bahaya merokok berpengaruh terhadap tindakan merokok seseorang. Hal ini berhubungan dengan ingatan yang baik terhadap reklame tersebut.

\section{i. Hubungan Reklame Rokok dengan Perilaku}

Dari hasil penelitian didapat bahwa $\mathrm{p}=0,015<$ alpha $=0,05$, ini berarti Ha diterima yang artinya bahwa ada hubungan keterpaparan reklame rokok dengan perilaku merokok pada pelajar di SMA Negeri 4 Kota Pematangsiantar.

Hasil penelitian ini sejalan dengan penelitian Hasanah dan Sulastri (2012) yang menunjukkan ada hubungan dukungan iklan rokok dengan perilaku merokok remaja. Hal ini memberikan dampak negatif bagi perilaku merokok remaja, remaja yang gemar melihat iklan rokok maka akan lebih tertarik untuk merokok.

\section{KESIMPULAN}

Berdasarkan hasil penelitian, maka dapat disimpulkan bahwa:

a. Ada hubungan reklame rokok dengan pengetahuan pelajar yang ada di SMA Negeri 4 Kota Pematangsiantar.

b. Ada hubungan reklame rokok dengan sikap pelajar yang ada di SMA Negeri 4 Kota Pematangsiantar.

c. Tidak ada hubungan reklame rokok dengan tindakan pelajar yang ada di SMA Negeri 4 Kota Pematangsiantar.

d. Ada hubungan reklame rokok dengan perilaku pelajar yang ada di SMA Negeri 4 Kota Pematangsiantar.

\section{SARAN}

\section{a. Bagi Pelajar SMA Negeri 4 Pematangsiantar}

Menyarankan kepada pelajar yang merokok untuk berhenti merokok, menambah pengetahuan tentang rokok dengan cara mengikuti seminar maupun pendidikan kesehatan tentang rokok khususnya bahaya merokok.

\section{b. Bagi SMA Negeri 4 Pematangsiantar}

Melakukan pemeriksaan terhadap pelajar secara rutin untuk menghindari adanya pelajar yang membawa rokok ke sekolah, menghisap rokok di lingkungan sekolah,. Memberikan sangsi kepada para guru yang merokok di lingkungan sekolah mungkin dapat membantu.

\section{c. Bagi Dinas Pendidikan Kota Pematang Siantar}

Menghimbau kepada seluruh sekolah untuk memberikan pendidikan kesehatan maupun penyuluhan stiap bulan khususnya tentang bahaya merokok bagi kesehatan, melakukan pemantauan terhadap reklame rokok yang ada di sekolah khususnya di kantin sekolah serta di lingkungan sekolah yang seharusnya reklame tersebut sesuai dengan peraturan tidak boleh dipajang.

\section{d. Bagi Dinas Kesehatan Kota Pematang Siantar}

Bekerjasama dengan pemerintah kota untuk membuat kebijakan terkait KTR serta mentertibkan pemasangan reklame rokok yang tidak pada tempatnya, membuat peraturan terkait dengan pemasangan reklame rokok dan juga meniadakan event-event yang di sponsori oleh rokok. 
Maswan D, Juliandi H, Basyariah L, Saiful B : Hubungan Reklame Rokok Dengan Perilaku Merokok Pelajar SMA Negeri 4 di Kota Pematangsiantar Tahun 2017

\section{DAFTAR PUSTAKA}

Attarahim dkk. 2015. Studi Sikap khalayak konsumen terhadap pesan peringatan bahaya merokok dalam iklan dan kemasan rokok, fakultas ekonomi dan ilmu sosial, universitas bakrie.

Aula, Lisa Ellizabet., 2010. Stop Merokok. Yogyakarta: Garailmu.

Bart, Smet, (1994). Psikologi Kesehatan. PT. Gramedia Widiasarana Indonesia. Jakarta.

Baskoro K. 2005. Hubungan antara sikap terhadap label peringatan bahaya merokok pada kemasan rokok dengan intensitas berhenti merokok, Fakultas Psikologi, Universitas Islam Indonesia Yogyakarta.

Dewanta CDP. 2013. Hubungan antara Intensitas Terpaan Iklan Rokok dan Tingkat Konformitas Peer Group dengan Pengambilan Keputusan Merokok Dikalangan Mahasiswi di Semarang. [Tesis Ilmiah]. Semarang: Universitas Diponegoro.

Fitri. Pengertian Anak Tinjauan secara Kronologis dan Psikologis. In : http://duniapsikologi.dagdigdug.com/2008/11/19/pengertian-anak-tinjauan-secara kronologis-dan-psikologis/ (akses: 6 Desember 2016)

Istiqomah, Umi. 2003. Upaya Menuju Generasi Tanpa Merokok Pendekatan Analisis Untuk Menangulangi Dan Mengantisipasi Remaja Merokok. Surakarta: CV. SETIA AJI

Khairul, Ahmad. 2014. Faktor-faktor yang memengaruhi perilaku merokok pada remaja di SMA Swasta Taman Siswa Malang.

Kholid A. 2012. Promosi Kesehatan Dengan Pendekatan Teori Perilaku, Media dan Aplikasinya. Jakarta: PT Raja Grafindo Persada.

Komalasari, D., Helmi, A.F., 2008. Faktor-faktor Penyebab Perilaku Merokok Pada Remaja. Universitas Gadjah Mada Press.; Available from: http://avin.staff.ugm.ac.id?data/jurnal/perilaku_merokok_avin.pdf. (Accessed 2017 January 05 )

Kusuma, ARP. 2011. pengaruh rokok terhadap kesehatan gigi dan mulut, majalah ilmiah sultan agung.

Kuswandi, Wawan., 2011. Komunikasi Massa-Sebab Analisis Media Televisi. Jakarta: Rineka Cipta.

Laventhal dan Pitaloka. 2006.Perilaku Merokok pada Remaja. www.digilib.unimus.ac.id. Diunduh pada tanggal 3 januari 2017, pukul 15.50 WIB

Mangoenprasodjo, A. Setiono dan Hidayati, Sri Nur., 2005. Hidup Sehat Tanpa Rokok. Yogyakarta: Pradipta Publishing. 
Maswan D, Juliandi H, Basyariah L, Saiful B : Hubungan Reklame Rokok Dengan Perilaku Merokok Pelajar SMA Negeri 4 di Kota Pematangsiantar Tahun 2017

medan.tribunnews.com > Sumut13 Jun 2016 - ... Peraturan Daerah (Perda) kawasan tanpa rokok kan belum ada,' ... 2012, di jalan protokol Pematangsiantar masih terpampang iklan rokok. Selasa, 20 desember 2016 pkl 08, ${ }^{30}$ Wib.

Mukuan, S.E. 2012. Hubungan antara pengetahuan dan sikap tentang bahaya merokok bagi kesehatan dengan tindakan merokok pada pelajar SMK Kristen Kawangkoan.

Mu'tadin, Z. (2002). Remaja dan rokok, www.e-psikologi.com. Diambil Pada Tanggal 10 Desember 2016

Neneng, N. 2013. Hubungan iklan rokok dengan tindakan merokok pada mahasiswa di UIN Jakarta.

Nurmayunita, dewi. Hubungan antara pengetahuan, paparan media iklan dan persepsi dengan tingkat perilaku merokok siswa SMK

Ogden, Jane. 2000. Health Psychology. Buckingham : Open University.

Potter, P.A, Perry, A.G. Buku Ajar Fundamental Keperawatan : Konsep, Proses, Dan Praktik. Edisi 4.Volume 1.Alih Bahasa : Yasmin Asih, dkk. Jakarta : EGC.2005.

Rachmat M., Thaha RM., Syafar M. 2013. Perilaku Merokok Remaja Sekolah Menengah Pertama. Jurnal Kesehatan Masyarakat Nasional. Volume 7. Nomor 11. Juni 2013. ISSN 1907-7505.

Riskesdas. 2013. Riset Kesehatan Dasar. 2013. Jakarta: Badan Penelitian dan Pengembangan. litbang.depkes.go.id

Riskesdas. 2010. Riset Kesehatan Dasar. 2013. Jakarta: Badan Penelitian dan Pengembangan. litbang.depkes.go.id

Sarwono, Sarlito W. (2008). Psikologi Remaja. Jakarta: PT Raja Grafindo Persada

Sitepoe M. Kekhususan rokok Indonesia. Jakarta: Grasindo, 2000: 12-30.

Sastroasmoro, S. 2011. Dasar-Dasar Metodologi Penelitian Klinis. Jakarta : Sagung Seto.

Tarwoto, Aryani R., Nuraeni A., Tauchi SN., Aminah S., Sumiati, Dinarti, Nurheni H.,

Saprudin, AE., Chairini, R. 2015. Kesehatan Remaja: Problem Dan Solusinya. Jakarta: Salemba Medika 